\title{
Renal disease screening: a potential tool for reducing health inequity
}

\author{
Rastreamento para doença renal: uma ferramenta em potencial para reduzir a \\ desigualdade na saúde
}

\author{
Paulo Andrade Lotufo' \\ Faculdade de Medicina da Universidade de São Paulo (FMUSP), São Paulo, Brazil
}

'MD, DrPH. Full Professor, Department of Internal Medicine, Faculdade de Medicina da Universidade de São Paulo (FMUSP), São Paulo, Brazil.
The impact of chronic kidney disease on mortality, quality of life and cost of medical care is rising worldwide, such that it now affects $8-16 \%$ of the world population. ${ }^{1}$ The Global Burden of Diseases index, which ranks the causes of deaths, has revealed that as the underlying cause of death, chronic kidney disease (CKD) jumped from $34^{\text {th }}$ position in 1990 to $18^{\text {th }}$ in $2013 .^{2}$ However, although the use of mortality statistics to ascertain temporal trends or make geographic comparisons has been helpful in charting other chronic diseases, this has not been the case for CKD. The reason for this is that when diabetes and CKD are mentioned together on a death certificate, the underlying cause is frequently stated as "diabetes without complications" and not "chronic kidney disease" or "diabetic kidney disease". ${ }^{3}$ Consequently, to ascertain the situation of CKD in countries like Brazil, other types of information are needed, such as registries, reports of medical procedures and epidemiological studies. ${ }^{4-7}$

In Brazil, data from the National Dialysis Registry and the Ministry of Health have shown that over 10,000 people are currently undergoing kidney replacement therapy. ${ }^{4}$ de Moura et al. analyzed data from the Brazilian National Health System on 280,667 patients with end-stage renal disease who received publicly financed kidney replacement therapy for at least three consecutive months. Men (57.2\%) and people aged 45-64 years (43.4\%) were predominant. The underlying causes of CKD were hypertension (20.4\%), diabetes $(12.0 \%)$ and glomerulonephritis (7.7\%). The annual increase in the prevalence of people under dialysis from 2000 to 2012 was $3.6 \%$ (95\% confidence interval, CI: $+3.2 \%$ to $+4.0 \%$ ) and the average annual change in incidence was $+1.8 \%$ /year $(+1.1 \%$ to $+2.5 \%) .{ }^{5}$

The prevalence of CKD among apparently healthy people was analyzed among the participants of the Brazilian Longitudinal Study of Adult Health (ELSA-Brasil). ${ }^{6,7}$ This was evaluated during baseline visits (2008-2010) to 14,636 civil servants aged 35 to 74 years. The definition of CKD based on albuminuria (albumin-to-creatinine $\geq 30 \mathrm{mg} / \mathrm{g}$ ) and glomerular filtration rate $<60 \mathrm{ml} / \mathrm{min} / 1.73 \mathrm{~m}^{2}$ ). The glomerular filtration rate was obtained through an equation devised by the Chronic Kidney Disease Epidemiology Collaboration (CKD-EPI), which was derived from pooled data from clinical studies in the United States. ${ }^{8}$ In ELSA-Brasil, the frequency of albuminuria or low glomerular filtration rate, alone or in combination, was related to aging, lower socioeconomic status and self-reporting as black. Risk factors such as smoking, dyslipidemia, hypertension and diabetes were directly correlated with CKD. However, these risk factors did not explain the socioeconomic differences, i.e. the higher prevalence of CKD among the elderly, less affluent people and blacks. ${ }^{9}$

One point to emphasize is that ELSA-Brasil researchers did not correct the glomerular filtration rate for race in the manner proposed by the CKD-EPI consortium. ${ }^{8}$ The reason for their race correction was the greater mass muscle described in the African-American population. However, in contrast with research conducted in the United States, three independent studies in different Brazilian cities did not show that correction for black race was useful for the Brazilian population. ${ }^{10-12}$ These conclusions were the same as those relating to black people living in 
Ghana and South Africa. ${ }^{13,14}$ In the light of these results in Brazil and Africa, there is no reason for medical laboratories in Brazil to keep on presenting glomerular filtration rates corrected for race.

Although the U.S. Preventive Services Task Force concluded that the "evidence is insufficient to assess the balance of benefits and harms of routine screening for CKD in asymptomatic adults," 15 we consider that creatinine measurements should be more widely used, so that glomerular filtration rates are not just estimated for people with hypertension or diabetes. As shown by the ELSA-Brasil results, socioeconomic status was inversely associated with $\mathrm{CKD}$ prevalence. Consequently, screening for CKD within primary care, especially at units located in places with poor and less educated populations, needs to evaluate this better: not only from a cost-effectiveness perspective but also from the perspective of the necessity to reduce inequity within the Brazilian population.

\section{REFERENCES}

1. Jha V, Garcia-Garcia G, Iseki K, et al. Chronic kidney disease: global dimension and perspectives. Lancet. 2013;382(9888):260-72.

2. GBD 2013 Mortality and Causes of Death Collaborators. Global, regional, and national age-sex specific all-cause and cause-specific mortality for 240 causes of death, 1990-2013: a systematic analysis for the Global Burden of Disease Study 2013. Lancet. 2015;385(9963):117-71.

3. Rao C, Adair T, Bain C, Doi SA. Mortality from diabetic renal disease: a hidden epidemic. Eur J Public Health. 2012;22(2):280-4.

4. Sesso RC, Lopes AA, Thomé FS, et al. Relatório do Censo Brasileiro de Diálise Crônica 2012 [Report of the Brazilian Chronic Dialysis Census 2012]. J Bras Nefrol. 2014;36(1):48-53.

5. de Moura L, Prestes IV, Duncan BB, Thome FS, Schmidt MI. Dialysis for end stage renal disease financed through the Brazilian National Health System, 2000 to 2012. BMC Nephrol. 2014;15:111.

6. Lotufo PA. Construção do Estudo Longitudinal de Saúde do Adulto (ELSA-Brasil) [Setting up the Longitudinal Study for Adult Health (ELSA-Brasil)]. Rev Saúde Pública. 2013;47 Suppl 2:3-9.

7. Schmidt MI, Duncan BB, Mill JG, et al. Cohort Profile: Longitudinal Study of Adult Health (ELSA-Brasil). Int J Epidemiol. 2015;44(1):68-75.

8. Levey AS, Stevens LA, Schmid CH, et al. A new equation to estimate glomerular filtration rate. Ann Intern Med. 2009;150(9):604-12.

9. Barreto SM, Ladeira RM, Duncan BB, et al. Chronic kidney disease among adult participants of the ELSA-Brasil cohort: association with race and socioeconomic position. J Epidemiol Community Health. 2015; pii: jech-2015-205834.

10. Zanocco JA, Nishida SK, Passos MT, et al. Race adjustment for estimating glomerular filtration rate is not always necessary. Nephron Extra. 2012;2(1):293-302

11. Veronese FV, Gomes EC, Chanan J, et al. Performance of CKD-EPI equation to estimate glomerular filtration rate as compared to
MDRD equation in South Brazilian individuals in each stage of renal function. Clin Chem Lab Med. 2014;52(12):1747-54.

12. Barcellos RC, de Matos JP, Kang HC, Rosa ML, Lugon JR. Comparação dos níveis séricos da creatinina entre diferentes categorias de raça/ cor em uma população brasileira [Comparison of serum creatinine levels in different color/race categories in a Brazilian population]. Cad Saude Publica. 2015;31(7):1565-9.

13. van Deventer HE, George JA, Paiker JE, Becker PJ, Katz IJ. Estimating glomerular filtration rate in black South Africans by use of the modification of diet in renal disease and Cockcroft-Gault formulas. Clin Chem. 2008;54(7):1197-202.

14. Eastwood JB, Kerry SM, Plange-Rhule J, et al. Assessment of GFR by four methods in adults in Ashanti, Ghana: the need for an eGFR formula for lean African populations. Nephrol Dial Transplant. 2010;25(7):2178-87.

15. Moyer VA; U.S. Preventive Services Task Force. Screening for chronic kidney disease: U.S. Preventive Services Task Force recommendation statement. Ann Intern Med. 2012;157(8):567-70.

Conflict of interest: Honoraria from Abbvie Brazil and Abbott Brazil for lectures Sources of funding: None

Date of first submission: December 15, 2015

Last received: December 15, 2015

Accepted: December 15, 2015

\section{Address for correspondence:}

Paulo Andrade Lotufo

Centro de Pesquisa Clínica e Epidemiológica, Hospital Universitário,

Universidade de São Paulo

Av. Prof. Lineu Prestes, 2.565

Butantã — São Paulo (SP) - Brasil

Tel. (+55 11) 3091-9300

E-mail:palotufo@hu.usp.br 